\title{
PRECEDENT AND CUSTOM: A RESPONSE TO VERDIER AND VOETEN
}

\author{
Jens David Oblin*
}

Verdier and Voeten have offered a new explanatory theory of compliance with customary international law. ${ }^{1}$ The more typical rational choice story is that states comply with custom in order to prevent their partners from retaliating against them with defections of their own, either in the context of that norm or in some other context, or to avoid negative reputational consequences with third parties. In order to avoid the negative consequences of partner defection, states comply with customary norms because doing so promotes their self-interest.

Verdier and Voeten offer a different rational choice account. They argue that states comply with customary international law because they worry that their lack of compliance will generate a particular type of precedent whose consequences will be problematic. ${ }^{2}$ Specifically, defection from the norm might generate a precedent that either the norm has collapsed or that the norm has changed in some important way. This precedent might be the first step in the formation of new law-law that might work to the disadvantage of the state if it becomes enshrined as a new custom. ${ }^{3}$ In some cases a state may wish to carve out for its situation a small exception to the norm of customary international law. ${ }^{4}$ But true exceptions are unstable; if there are too many of them, the exception itself is transformed into a new rule. For some states, that is a dangerous situation that they would prefer to avoid. While states are frequently tempted by a have-a-cake-and-eat-it-too strategy, they worry that their defection will undermine the very rule that they will need to rely on later. So they follow the rule now, even if they are not concerned with retaliation, rather than risk creating a precedent that will come back to haunt them later.

This argument depends upon the long-term thinking of the state. The state determines that defection today will create a poor precedent for tomorrow, thus undermining the strategic position of the state in a future round of the game-i.e. benefit today, burden tomorrow. A myopic agent will defect today and ignore the negative consequences that come to fruition tomorrow. But a rational agent with a sophisticated view of rationality's long-term consequences will comply today in order to secure the benefits tomorrow. ${ }^{5}$ Or, to put

* Professor of Law at Cornell Law School and the author of THE ASSAULT ON INTERNATIONAL LAW (2015).

Originally published online 5 Apr. 2015.

${ }^{1}$ See Pierre-Hugues Verdier and Erik Voeten, Precedent, Compliance, and Change in Customary International Law: An Explanatory Theory, 108 AJIL 389 (2014).

${ }^{2} \underline{I d}$. at 401 (arguing that "states may comply because they expect that their defection would undermine a cooperative norm whose continued existence they value").

${ }^{3} \underline{I d}$. at 403 . Verdier and Voeten conclude that the analysis holds even for strong states. See $\underline{I d}$. at 409 ("When great powers decide how to behave, they are often explicitly concerned with the precedential impact of their decisions. For example, as it elaborates its policy regarding the use of unmanned drones, the United States is aware that it is setting precedents that will affect the evolution of CIL.").

${ }^{4} \underline{I d}$. at 391 (discussing desire to "defect and free ride on continued compliance by others").

5 See generally, Bryan Skyrms, The Shadow of the Future, in Rational COMmitMent and SOCIAL Justice: Essays FOR GREGory KAVKA 12 (Jules L. Coleman \& Christopher W. Morris eds., 2007).

$$
\text { ASIL and Jens David Ohlin }
$$


the point another way, states comply with custom today in order to avoid creating a precedent that might work to their disadvantage tomorrow.

If this account is descriptively correct, it shows that states not only act as rational agents, but it also shows that they act with a level of strategic sophistication: forgoing benefits today in order to avoid being saddled with heavy burdens tomorrow. If Verdier and Voeten are correct, this also shows that the "typical" view of international custom is either incorrect or at the very least incomplete; fears of retaliation or reputational harm are not the driving force behind state compliance with international custom. Fear of negative precedent is more important.

I wish to discuss two issues with the account offered by Verdier and Voeten. The first one is considered in their article but bears further brief mention because of its importance: does their account replace or supplement the typical story of reputation and retaliation? The second issue is one they do not consider, which is not surprising because it is not a common one in the international law literature on compliance: What happens to custom in oneshot scenarios when long-term interests play little or no role? ${ }^{6}$

First, does the Verdier and Voeten theory replace or supplement the typical compliance theory? Indeed, by its own terms, the precedent theory does not negate or demonstrate the complete irrelevance of retaliation and reputation. Indeed, the retaliation and reputation account is conceptually sound. So there are two ways of reading the precedent argument. In its broadest instantiation, it could be a full replacement for the retaliation account. But on its narrowest form, the precedent theory is a mere supplement to the retaliation story, rounding out the specifics of compliance by consideration of the multiple long-term implications of defectionsome of which have been ignored by the literature. Verdier and Voeten meant to rectify those deficiencies; the goal is to produce a fuller account of compliance.

Verdier and Voeten's own understanding of their account is that it falls in between the modest and aggressive versions: although it is not designed to crowd out alternate explanations for state compliance, Verdier and Voeten apparently believe that concerns regarding precedent play a greater role in state compliance than do concerns about retaliation, reputation, and reciprocity. ${ }^{7}$ When compliance theorists ignore the power of precedent, Verdier and Voeten think the theorists have missed a crucial link-and in this regard they are surely correct. Whether precedent is more important than the other factors is another matter. (It should be noted that while Verdier and Voeten are concerned about a particular species of reciprocity in their precedent theory, it is a far more diffuse type of reciprocity than one finds in the typical theories of reputation and reciprocity.)

Second, what remains of compliance with custom in situations where states cannot appeal to long-term interests? There are several reasons why one should ask about these situations. For example, customary rules regarding warfare certainly apply in situations where the future casts a long shadow over present decisionmaking, but they also apply in situations where the shadow is short or nonexistent. ${ }^{8}$ Indeed, during war, states may face destruction and may be forced to make decisions about complying with custom without knowing whether or not they will endure in the future. If the state will cease to exist (because they lose the armed conflict), the state has no reason to worry about precedent (or retaliation) either. Other examples include states with an extremely high discount rate (and therefore prioritize present interest over future interests), or

6 See, e.g., Andrew T. Guzman, Saving Customary International Law, 27 Mich. J. INT’L L. 115 (2005); George Norman \& Joel P. Trachtman, The Customary International Law Game, 99 AJIL 541 (2005); Jack L. Goldsmith \& Eric A. Posner, A Theory of Customary International Law, 66 U. CHI. L. REV. 1113, 1115 (1999).

7 Verdier and Voeten, supra note 1, at 432 (concluding that states do not break or honor human rights obligations on the basis of reciprocity, but "[t]hat said, many states appear to be preoccupied with precedent").

${ }^{8}$ For a study of compliance with the laws of war, see generally JAMES D. MORROW, ORDER WITHIN ANARCHY: THE LAWS OF WAR AS AN INTERNATIONAL INSTITUTION (2014). 
tyrants who desire to hold on to power at all costs. In the latter case, although the state might endure, the tyrant may not, thus eliminating from his strategic vision calculations regarding future interactions. And then one must ask what pull international law has on the tyrant's decision-making.

There are other, less extreme, situations where the shadow of the future might be irrelevant. A particular situation might be relatively one-off so that it is unlikely to repeat itself for that particular state. I am not thinking here of the case where the situation will never repeat itself at all (because then there would be no need for the rule), but rather that it is unlikely to happen again for that particular state. In that case, the state might not care so much about the precedent because the rule is not likely to be applicable to them again. Verdier and Voeten should predict defection in that case. But a retaliation theory would predict compliance, possibly, if the state worries that its partners will retaliate in other domains involving other legal issues.

However, I think there is more to be said about these one-shot scenarios, although one needs to leave the relatively safe confines of descriptive theory to do so. In some situations, it might be rational for a state to comply with a particular norm of international law, even if there is no future to cast a shadow on the present decision. In other words, compliance might be rationally justified even in cases where fear of retaliation, or fear of negative precedent (in the sense used by Verdier and Voeten), is irrelevant.

States, just like individuals, reason using plans and strategies. ${ }^{9}$ Instead of deciding at each moment in time whether a particular decision will produce a better outcome, a rational agent will formulate plans that will make its life go better overall. Then, the rational agent executes individual actions that constitute elements of the plan. This structure is pertinent to international law. Rational agents formulate plans that involve assenting to, or supporting, international norms; these agents then rationally follow through on those plans by acting in according with those international norms. As I argue in The Assault on International Law ${ }^{10}$ rational agents do not obsessively reevaluate their strategy or plan at each moment in time, looking for opportunities for defection. Rather, agents evaluate whether a particular plan is rationally justified at the beginning of the plan, then if circumstances are not greatly changed, follow through with the individual actions necessary to bring the plan to fruition.

One might ask where rational agents can, or should, reevaluate a plan or strategy based on changed circumstances. If indeed the agent receives new information that was unavailable at the time the plan was formulated, it is indeed rationally justified to reevaluate the utility of the original plan. However, it is not justified for an agent to reevaluate a plan's effectiveness simply because the benefits have already accrued and all that is left are the burdens. ${ }^{11}$ In that situation, defecting from the plan threatens the stability of plans and makes the agent's best interests subordinated to the whims and fancy of the moment, and prevents him or her from engaging in larger chunk commitments that can realize advantageous positions. ${ }^{12}$

Classical economists would argue that an agent in this situation should follow through on the plan because doing so signals trustworthiness to potential partners; a defecting agent risks being labeled as an uncooperative outcast. Verdier and Voeten would argue that plan-following decreases the likelihood negative precedent. What both share is a focus on the long-term future, on future iterations of the game.

I would argue that plan stability is warranted even in the case of a one-shot game. Simply put, an agent should follow through and fulfill the elements of a plan-including complying with binding norms of inter-

${ }^{9}$ On the planning theory of human agency, see Michael E. Bratman, Intention, Plans and Practical Reason (1987).

10 Jens D. Ohlin, The Assault on InTERnational Law (2015).

11 This conclusion is demonstrated by Gauthier's work. See David Gauthier, Retbinking the Toxin Puzzle, in RATIONAL COMMITMENT AND Social Justice: Essays for Gregory KavkA 47, 57 (Jules L. Coleman \& Christopher W. Morris eds., 2007); David Gauthier, Commitment and Choice: An Essay on the Rationality of Plans, in ETHiCs, RATIONALITY, AND ECONOMiC BeHAVIOR 217,221 (Francesco Farina et al. eds., 1996).

12 See David Gauthier, Assure and Threaten, 104 ETHics 690 (1994). 
national law-if and only if following through on the original commitment is one element of a rationally justified plan. A rationally justified plan is a plan that makes the agent's life go better over all. When applied to international law, this suggests that states should comply with their international commitments, irrespective of any impact on reputation or precedent, just as long as the formation of the plan was rationally justified in the first instance and the state has not acquired new information. ${ }^{13}$

Of course, technically speaking, nothing in the Verdier and Voeten thesis crowds out this account of rationality, because their argument is descriptive while the other is normative. They attempt to explain why states act the way they do. Look at future precedent they say, and their argument makes sense. On the contrary, the normative argument presented above focuses on what states ought to do as rational agents. One should never forget that rationality is a value, a norm to which all agents, out of logical necessity, remain committed to. As such, both sides of the descriptive-normative divide need to be part of the discussion.

That discussion needs to focus, as a preliminary matter, on what rationality is and what it requires, before we proceed to the second step and start asking questions about the rational behavior of states. Most people argue that rationality requires that an agent pursue his best response at each atomistic moment in time. But others, including myself, believe that rationality requires acting in accordance with a plan that makes the agent's life go better overall. This is a big difference and certainly impacts any theory of compliance.

13 See OHLIN, supra note 10, at 119-153 (2015). 